\title{
Hiperparatiroidismo nutricional secundário e suas alterações na cavidade oral - relato de caso
}

[a] Universidade Federal de Santa Maria (UFSM), Santa Maria, RS, Brasil

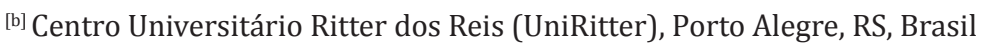

[c] Equident Odontologia Equina, Porto Alegre, RS, Brasil

[d] Clínica Hípica, Porto Alegre, RS, Brasil

*Autor correspondente

e-mail: izauravscherer@gmail.com

\section{Resumo}

Hiperparatireoidismo nutricional secundário ou osteodistrofia fibrosa, também conhecido como "doença da cara inchada", é um distúrbio relacionado ao manejo nutricional errôneo em equinos. Ocorre devido ao aumento da liberação do hormônio PTH (paratormônio), o qual atua retirando cálcio dos ossos e liberando-o para a corrente sanguínea. 0 excesso do mineral fósforo (P) na dieta faz com que o cálcio (Ca) dos ossos seja retirado para que o equilíbrio na relação Ca:P seja mantido. Os primeiros ossos a sofrerem com a remoção do cálcio são os ossos da face, pois apresentam uma deposição excessiva de tecido conjuntivo e osteóide por estímulo dos osteoblastos, levando ao aumento progressivo na espessura dos ossos. Posteriormente, os ossos afetados são mandíbula, crânio, costelas, vértebras e ossos longos. 0 objetivo desse trabalho é relatar o caso de um equino macho, 20 anos, com osteodistrofia fibrosa, que apresentava emagrecimento progressivo, dificuldade para se alimentar e ingerir água, e anormalidades dentárias secundárias à doença. 0 animal estava sob confinamento, recebendo ração comercial e feno de alfafa. Seu escore corporal (ECC) era 3, demonstrava dificuldade de locomoção, dispneia, respiração ruidosa e aumento de volume dos ossos da face (incisivo, nasal, mandibular e alveolar). No exame clínico, a suspeita foi osteodistrofia fibrosa. Na avaliação intraoral, foi observado aumento de volume dos ossos alveolares incisivos, maxilares e mandibulares, além de sangramento nos espaços interdentais e mobilidade grau 1 nos dentes de todas as arcadas. Devido à deformação dos ossos da face, ocorreu obstrução da passagem de ar em conchas nasais e seios paranasais, resultando em respiração ruidosa nas vias aéreas superiores e dispneia. Adicionalmente, foram feitas radiografias de face, que revelaram radiopacidade em seios paranasais, indicativo de presença 
de tecido fibroso nos compartimentos rostrais e caudais, e perda de densidade óssea mandibular, maxilar e em alvéolos dentais. No exame bioquímico, as concentrações séricas de Ca e P não estavam alteradas, contudo a fosfatase alcalina (FA) estava elevada $(675,68 \mathrm{mg} / \mathrm{dl}) .0$ hemograma revelou anemia, leucopenia, neutropenia e desidratação. Neste caso, devido ao avanço da osteodistrofia fibrosa e de comprometimento da saúde do animal, foi recomendada a eutanásia. A instabilidade dentária presente nesta doença, gerada pela reabsorção alveolar, promove dor mastigatória e, por fim ,perda de peso progressiva, não sendo raros os casos de perda dental. Alguns sinais clínicos como o sangramento nos espaços interdentais e a mobilidade dental devem ser diferenciados de doença periodontal. No caso da osteodistrofia fibrosa, a periodontite é disseminada e associada ao aumento de volume alveolar. Síndrome de hipercementose odontoclástica equina pode ser confundida com esta doença, porém ela cursa com hipercementose, perda da integridade do periodonto e fístula. $O$ fato do animal estar sob constante confinamento, sem exposição solar, pode ter sido o fator desencadeante, considernado-se que a radiação ultravioleta B da luz solar estimula a produção da pré-vitamina D, que, por sua vez, é convertida nos rins para a forma biologicamente ativa, a vitamina D, e sem esta não é possível que o organismo faça a absorção do cálcio. Os níveis bioquímicos de Ca e P foram normais por ser um processo avançado e porque mecanismos homeostáticos tendem a compensar os níveis destes minerais. Já a FA estava elevada devido ao aumento da atividade osteoblástica presente nesta doença. A eutanásia foi a opção escolhida devido ao comprometimento da saúde do animal e ao avanço da doença, uma vez que não existe regressão dos sinais clínicos, e pelo sofrimento respiratório.

Palavras-chave: Hiperparatiroidismo nutricional secundário. Osteodistrofia fibrosa. Cara inchada. 